Proceedings of the Seminar on the Social and Economic Effects

of Earthquake Prediction, 12 October, 1977.

\title{
THE ROLES OF CENTRAL AND LOCAL GOVERNMENT IN
}

\author{
PRE-DISASTER PLANNING
}

\author{
Sir Patrick O'Dea*
}

For the purposes of this paper, it is assumed that the accurate prediction of earthquakes, both as to time and place, is a practical proposition. The extent to which this is true in 1977 has already been discussed in Professor Evison's paper, and quite clearly, although tremendous strides have been made, we are still quite some way from achieving predictions of this accuracy.

My task is to gauge what different responsibilities need to be accepted by central and local government if it were possible to predict that an earthquake would strike in or about a particular area and round about a particular day and time.

\section{EXISTING BASIS FOR CIVIL DEFENCE}

The Civil Defence Act is framed so as to place prime responsibility for civil defence preparations on the local authorities, backed up by co-ordinated use of regional and national resources which can be mobilised to assist in accordance with pre-determined plans. This approach is based on the premise that lisaster can strike anywhere at any time, and that the only people who can give help in the first few hours or, in the case of a more serious disaster, perhaps the first few days, are the people themselves in the affected area. So present civil defence planning is essentially related to the identification of local resources, the training of key personnel, and the preparation of plans which will provide for the co-ordinated use of the available local resources, so that affected areas can help themselves until outside assistance can be brought to bear.

So far, this approach has worked well, and while, mercifully, there have been no major disaster to fully test the civil defence organisation in this country, there have been numerous cases where local communities have dealt with minor, or relatively minor disasters in their own areas without much need to call on outside help. The Inangahua earthquake clearly demonstrated the necessity for local preparations, as with the loss of all communications, including road and rail, the people of the West Coast necessarily had to look after themselves for many hours before outside help could be provided.

\section{CONSEQUENCES OF EARTHQUAKE PREDICTION}

Civil Defence does not undertake much pre-disaster planning. It is geared for action in the event of a disaster occurring or being imminent - and by 'imminent' I

\footnotetext{
* Secretary, Department of Internal Affairs
}

mean something such as a flood or a tsunami, which it is known will strike a locality within a matter of hours, or a day at the most.

Under existing legislation and plans, the local civil defence organisations come into operation only when an actual civil defence emergency exists. The organisations do not normally have any responsibility for recommending precautionary measures which can be applied in advance in order to mitigate the effects of a disaster, such as ensuring that buildings are constructed to adequate earthquake resistant standards or are strengthened to those standards. An obvious exception to this were the precautions taken in advance by certain elements of civil defence organisations to cope with the possibility of any problems arising from the presence of nuclear powered ships.

This does not mean that there is no authority responsible for measures such as those mentioned. Local authority building bylaws include numerous provisions for types and strength of construction to resist certain forces of earthquake. Local authorities which can establish that they have adequate engineering advice available can be granted powers under the Municipal Corporations and the Counties Acts to require earthquake risk buildings to be strengthened or demolished. Similarly, flood protection works are undertaken by local authorities and catchment authorities in areas where there is a known flood risk. Again, it is common practice for earthquake faults in known active areas to be identified on planning schemes and for certain requirements to be written into planning codes as a result of this. In one district close to Wellington there are areas set aside for activities such as used car sales yards and similar types of low risk activity, solely because they are known to be especially at risk in the event of an earthquake.

The important point to note is that Government does not apply any coercion to local communities to take advantage of these statutory powers. It is up to local communities to determine the action to be taken and the degree of risk they are prepared to accept.

\section{EARTHQUAKE PREDICTION - LONG WARNING PERIOD}

Section 301A of the Municipal Corporations Act, and the corresponding provision of the Counties Act, which deals with the powers of councils in respect of buildings likely to be dangerous in an earthquake, is based on the premise that earthquakes of any given magnitude can strike anywhere at any time. clearly, if it were possible for the scientists 
to agree that some districts were more prone to the possibility of earthquakes than others, there would be a need to re-examine the premises on which the existing law is based. If some areas could be identified as being more earthquake prone than others, then increased powers to deal with unsafe buildings may need to be given to local authorities in these areas and, indeed, the Government might have to consider making the exercise of those powers mandatory. standard building bylaws, which already recognise three seismic zones relating to earthquake risk with differing force-resistant standards, and which presently are permissive, would almost certainly have to be made mandatory in respect of areas where the probability of earthquake is given a greater certainty. Those building standards which are framed for universal application may have to be altered to differentiate between areas of known earthquake risk and those of lesser risk.

But those of us who were involved with the preparation of section 301 of the Muricipal Corporations Act in 1968 will know that additional powers of this kind are not lightly given. The clash between the rights of the individual who owns property, as against the safety of the community at large, becomes very marked when legislation of this nature is mooted. Governments are reluctant to give increased powers of this kind unless the necessity for them is publicly accepted. The degree to which Governments would be prepared to apply coercion on local authorities to use wide powers affecting the rights of individuals would obviously have some relationship to the degree of certainty with which scientists could predict earthquakes.

Beyond the strengthening or demolition of buildings that are earthquake risks, and the removal of parapets or other unsafe structural features, or such obvious measures as enforced evacuation drills, there is little that could be done in terms of existing law for long-term measures to meet a predicted earthquake situation.

However, any improvement in the technique of earthquake prediction would, in my opinion, need to be matched by additional legislative authority to enable local authorities to deal more positively with earthquake risk situations.

\section{EARTHQUAKE PREDICTION - SHORT WARNING PERIOD}

It it were possible for scientists to predict with any degree of certainty that an earthquake would strike any particular area within a matter of days, or weeks, or even a month, then clearly the public would have to be informed and emergency measures instituted. Such obvious things as the evacuation of hospitals in the affected area to make room for casualties; the evacuation of old people and others who cannot look after themselves to safer areas; the compulsory evacuation of buildings considered to be, or suspected of being, earthquake risks; the giving of advice on how to store and preserve supplies of water and food; the promulgation of emergency public health measures; the readying of rescue equipment and the mobilisation of resources for dealing with an emergency; readily come to mind. All of these matters are provided for today under the Civil Defence Act and the plans for civil defence made under the authority of that Act, but they are designed to be implemented after the event, and not in advance of it. Clearly in the situation postulated, additional legal powers would be necessary to deal with emergency measures such as those indicated above.

I think this situation could be met by drafting emergency regulations which would given Government and local authorities wide powers to deal with emergencies of this kind. Such regulations, which would have to be kept up to date, could be put in cold storage until the need for their implementation arose. When it judged a situation had arisen where such emergency powers should be invoked, the Government could take immediate steps to implement the regulations giving it the necessary power to take action at the Government level, and those local authorities in the affected area the power to take appropriate measures at the local level.

These regulations, which would have some similarity to those prepared to be invoked in a war-time situation, would need to be fairly comprehensive, and should be capable of being applied wholly or in part, depending on the nature of the area likely to be affected (for example, highly built up, or sparsely settled) and the expected strength of the predicted earthquake.

Irrespective of the certainty or otherwise of earthquake prediction, the Ministry of Civil Defence is already examining the possible need for regulations of this kind. We are also looking at the possibility of pre-disaster planning that is, the codifying and promulgation of a set of simple precautions which could be acted upon throughout the country, and particularly in areas which are known to be of greater earthquake risk than others.

There is no reason why something like this could not be done today in advance of other disasters which are always possible, such as the sudden flooding of urban areas or the effects of tsunamis on low-lying areas of our coast.

It may be premature at this stage to widen the scope of the Civil Defence Act to cope with what I would term-for want of a better expression - planning for pre-disaster action in the event of an earthquake. There are, as I have illustrated, a number of existing provisions in this field in other legislation - in the Municipal Corporations and Counties Acts, and the Town and Country Planning legislation.

Possibly these are so far as we can go just now, but as earthquake prediction becomes a more exact science, as undoubtedly it will, then we must take positive action to provide the legal backing and the physical resources necessary to ameliorate the effects of earthquakes. One way this can be done is, as I have said, to prepare regulations which can be applied to any given district at an appropriate interval in advance of the shake. 
My conclusion is that there would be a whole new range of responsibilities placed on Government and local authorities if

earthquake prediction became a more exact science. Certainly there would be a need for us to examine existing laws in detail, and to determine with greater preciseness than has been possible in this paper, the additional legal obligations that would have to be imposed, and the extent to which such obligations should be undertaken by Government itself or be delegated to local

authorities in areas affected by predictions. 